\title{
Do Regulators Read the Literature? Bank Merger Regulation, 1963-1990*
}

\author{
ROBERT DEYOUNG \\ Office of the Comptroller of the Currency \\ Washington, D.C.
}

\section{Introduction}

During the early 1980s a series of events occurred that altered the regulatory, political, and scholarly underpinnings of bank merger regulation. New laws that deregulated financial institutions increased actual and potential competition in banking markets. Consistent with the laissez faire spirit of this deregulation, the Reagan Justice Department relaxed its enforcement of the merger antitrust laws. New banking cost studies produced lower estimates of optimal bank scale, suggesting that small banks might be more effective rivals of large full service banks than previously thought. New studies in industrial organization began to question the traditional notion that concentration and collusion are the root causes of excess profits, weakening one of the primary justifications for denying mergers of banks and nonbanks alike.

This paper explores whether the Federal Reserve Board of Governors' commercial bank merger policy changed around 1980, and whether these changes were consistent with contemporaneous regulatory, political, and scholarly developments. The determinants of the Board's merger policy both before and after the early 1980s are estimated using a binomial probit model. The results suggest that the Board revised its overall merger policy consistent with changes in the Justice Department's Merger Guidelines, but was only marginally influenced by changes in the banking cost and industrial organization literature. Although merger policy became more relaxed as Reagan appointees were added to the Board, the possibility that this loosening was a response to the increased competition in financial markets could not be dismissed.

\section{The Changing Regulatory Environment}

The Banking Acts of 1933 and 1935 were designed to stabilize the banking sector and prevent the reoccurrence of widespread bank failures. In addition to introducing insurance to protect small depositors in failed banks, these laws aimed to curb "excessive" competition among banks by capping the rates banks could pay to attract funds, allowing federal regulators increased control over entry by new banks, and restricting the services banks could provide. If judged by the virtual

*The author thanks Jeffrey Adams, Robert Elder, Stephen Rhoades, and two anonymous referees for their helpful comments, as well as Timothy Hoff for his research assistance. The views expressed in this paper are those of the author and do not necessarily represent the opinions of the Office of the Comptroller of the Currency. 
nonexistence of post-war bank failures, these laws were highly successful. By the 1970s, however, critics of regulation were arguing that this stability came at the cost of controlled deposit rates and unacceptably low levels of service, innovation, and operating efficiency. Though these arguments were based on theoretical rather than empirical evidence, they were successful. The Depository Institutions Deregulation and Monetary Control Act of 1980 and Garn-St. Germain Depository Institution Act of 1982 exposed banks to potential competitors from other geographic and product markets. The Acts eliminated interest rate ceilings, permitted thrifts to offer products previously limited to banks (e.g., consumer loans, commercial paper, trust accounts, credit cards), and allowed mergers between banks and thrifts and across state lines.

It seems sensible that bank regulators would have eased their merger policies in response to deregulation. Ceteris paribus, a merger of two incumbent banks holds less potential for anticompetitive effects if the market is open to greater numbers and types of competitors. In addition, allowing the market for corporate control to operate more or less freely would help identify and discipline those banks not making the efficiency gains envisioned by proponents of deregulation. It also seems sensible that bank merger policy after 1980 would have been shaped by a series of other phenomena that occurred around that time, including: changes in the economic theories of imperfect competition; changes in the empirical evidence necessary to support such theories; revised estimates of efficient scale in banking; a more laissez faire merger antitrust policy in general; and a shift in the political composition of the Board of Governors. Rhoades and Burke $[20,444]$ surveyed some of these changes, and concluded that "a strong confluence of political and economic developments provided the foundation" for an easing of bank and nonbank merger antitrust in the 1980s.

\section{The New Learning and Merger Antitrust}

The well-known reticence of the Reagan Administration to challenge mergers was a sharp contrast to the previous twenty years of strict merger policy that focussed on little else but restraining market concentration. The pre-Reagan policies were based on the conventional wisdom that high concentration allows oligopolistic coordination, which in turn leads to reduced output, increased prices, and excess profits. The "structure-performance" theory was supported by scores of empirical studies showing positive relationships between concentration and profits. The 1968 Department of Justice Merger Guidelines were consistent with this theory and evidence, employing rigid formulae based almost solely on market shares. The 1968 Guidelines were tight, allowing the DOJ to challenge mergers between firms with a combined market share of as little as $8 \%$, and in many cases Justice argued for artificially small market definitions that effectively tightened the Guidelines further. The liberal Warren Court proved an ally in these proceedings, since efforts to restrain concentration were consistent with that Court's interventionist social agenda.'

In the 1970s a "new learning" in industrial organization theory, usually associated with the University of Chicago, sought to explain the concentration-profits correlation without reference to collusion. Demsetz [7] and others argued that firms with competitive advantages over their rivals - superior service or product quality, efficiencies in production or distribution, etc.- - gain large market shares and high profits. Thus, high profit firms do tend to be found in highly concentrated markets, but only because the large market shares of these successful firms influence concentration statistics upward. In such cases, a highly concentrated market is said to have an

1. See Scherer and Ross [21, 176-94] for an historical overview of the U.S. government's merger antitrust policies. 
"efficient structure." The efficient-structure theory was naturally appealing to the pro-business Reagan Administration because it attributed business growth and profitability to efficient production and satisfied consumers. Baumol, Panzar, and Willig's highly influential Contestable Markets and the Theory of Industrial Organization [3], which emphasized that potential entry might adequately discipline market incumbents, also provided support for the Administration's laissez faire predilections. The influence of these theoretic developments are clearly present in the revised 1982 and 1984 Merger Guidelines, which increased the concentration levels necessary to invite a Justice Department challenge and relaxed the scrutiny of mergers when entry barriers were low.

The Department of Justice can file suit to undo mergers approved by the bank regulators that it feels are anticompetitive, but Justice is powerless to retroactively allow applications denied by the regulators. Thus, Justice can use the courts to force regulators to comply with a tightened merger policy, but not to bring regulators into line with a looser merger policy. This asymmetry gave bank regulators a range of policy choices during the 1980s: relax merger policy along with Justice at one extreme, or continue to practice a merger policy consistent with the relatively stricter pre-Reagan standards at the other extreme.

\section{The Empirical Literature in Industrial Organization}

The relationship between market concentration and market profits has been tested more often than any other relationship in industrial organization. In a survey of concentration-profits studies of (mostly) manufacturing industries, Weiss [27, 202] found that "the bulk of the studies show a significant positive effect of concentration on profits or margins." In a survey of similar studies of the banking industry, Gilbert $[10,636]$ concluded that "the better studies report a significant influence of market concentration on the performance measures, with signs implied by the structureperformance hypothesis." ${ }^{2}$ These results supported the theories of oligopoly and collusion on which the strict merger antitrust of the 1960s and 1970s rested.

The performance measures most often used in these studies were the return on assets, equity, or sales, aggregated at the market level. Proponents of the new learning criticized this approach, pointing out that aggregated data obscured important firm level relationships. Using non-financial firm level data, Ravenscraft [18] found no relationship between firm profits and market concentration, but a positive relationship between firm profits and market share. Using firm level data for commercial banks, Smirlock [22] found that market share dominated market concentration in explaining bank profits. Both authors concluded that the results supported the efficient structure hypothesis. In a study of small commercial banks, Rhoades [20] also found that market share was a source of high profits, but argued that, since this relationship was found in unconcentrated and highly concentrated markets alike, the results did not support the efficient structure hypothesis. ${ }^{3}$ In light of these and numerous other studies, Scherer and Ross [21] summarized the earlier concentration-profits results as "spurious, a construct of aggregating from the line of business to the industry level."

If the debate had ended with these studies, one would have expected the Board to deemphasize market concentration during the 1980s. However, the debate over the impact of concentration

2. Gilbert [10] drew this conclusion reluctantly, however, since only about half of the studies he reviewed found a significant relationship between concentration and performance. Gilbert also notes that the efficient-structure hypothesis had not yet been adequately tested for banking markets.

3. Rhoades [19] suggests that high market share may confer a product differentiation advantage that in turn allows a pricing premium. 
in banking markets remains unsettled to date. Many of the more recent studies exploit survey data to test the impact of concentration on prices rather than on profits, an approach that had been used frequently during the 1960s and 1970s with mixed results, perhaps due to poor quality price data. ${ }^{4}$ Hannan [11] found concentration to be positively related to loan rates. Berger and Hannan $[5,291]$ found a positive relationship between concentration and deposit rates, and concluded that the results "strongly supported the structure-performance hypothesis."

For the purposes of this study, it is important to recognize that this debate, the onset of which occurred at roughly the same time that other determinants of bank merger policy were changing, marked a potential unwinding of an earlier conventional wisdom.

\section{The Banking Cost Literature}

The Bank Merger and Bank Holding Company Act of 1966 [2] required bank regulators to deny mergers that substantially reduced competition unless "the anticompetitive effects of the proposed transaction are clearly outweighed in the public interest by the probable effect of the transaction in meeting the convenience and needs of the community to be served." Since efficient banks are better able to meet the convenience and needs of the community (lower prices, improved services), this legislation could be interpreted as encouraging regulators to allow mergers that generated efficiencies large enough to offset their anticompetitive effects.

The welfare tradeoff between market power and productive efficiency was formalized by Williamson [28]. The 1984 Merger Guidelines did not allow a full-blown Williamson efficiencies defense, but they allowed for the first time the antitrust authority to consider efficiencies if convincing evidence existed that those gains would not be achieved but for the merger. In practice, however, it is doubtful whether efficiencies were considered even at the margin. According to Scherer and Ross [21, 188], the Justice Department "accepted few if any merger efficiency defenses during the first three years" of the 1984 Guidelines, and the courts have never accepted efficiencies as the basis for allowing an anticompetitive merger. ${ }^{5}$

If bank merger regulators did consider efficiencies during the time period examined here (1963 to 1990), the focus would have been on scale economies. Prior to the 1980 s virtually all sizes of banks were thought to exhibit increasing returns to scale. Most banking cost studies produced negatively-sloped unit cost functions that asymptotically approached constant returns. Humphrey [15] discusses the deficiencies of these studies, and it is now generally accepted that this "L-shape" was an artifact of using the Cobb-Douglas functional form, a constant elasticity of scale specification incapable of producing a "U-shaped" unit cost function. In the early 1980s economists began substituting the translog functional form for the Cobb-Douglas. Humphrey [14] discusses the consequences of this change, and reviews the differences among the numerous trans$\log$ studies that followed. In the first of these studies, Benston, Hanweck, and Humphrey [4] concluded that the optimal-sized banking office was between $\$ 10$ and $\$ 25$ million (1978 dollars) of deposits, beyond which scale diseconomies set in. A large number of translog studies followed in quick succession; most of these studies found a U-shape as well, with modest scale economies exhausted below $\$ 100$ to $\$ 200$ million (current dollars), followed eventually by modest scale diseconomies. ${ }^{6}$

4. See Smirlock [22] and Gilbert [10] for a discussion of these earlier studies.

5. Brown Shoe (1962), Philadelphia National Bank (1963), and Proctor \& Gamble (1967) are the precedents.

6. Studies focussing exclusively on large banks did not appear until 1984. Many of these large bank studies found modest scale economies that were not exhausted until well above $\$ 1,000$ million in deposits. 
The first studies to test separately for scope economies appeared in 1984. Mester [16] and Clark [6] review the early part of this literature and report only a smattering of evidence of scope economies between only a few output pairs. The results suggest that full service banks offering a wide range of services have no cost advantage over financial "boutiques" specializing in a subset of those services.

Overall, the post-1980 cost studies suggested that bank mergers were less likely to produce cost savings-either by increasing a bank's size or by diversifying its product mix - than was previously thought. Although the revised Merger Guidelines considered cost efficiencies for the first time, the results in the banking cost literature made an efficiencies defense more difficult to justify.

\section{The Composition of the Board}

The relaxed concentration, entry barrier, and efficiency standards of the 1982 and 1984 Merger Guidelines were a clear a statement of the Reagan Administration's free market ideology. The revisions were also consistent with changes in the theoretical and empirical literature in industrial organization. To what degree the Guidelines were loosened in response to academic developments, or whether changes in the academic literature were a convenient justification for relaxing the Guidelines, is not clear. Regardless, Waldman [26, 127] reports that the revised Guidelines were an ex post confirmation of a shift in antitrust policy that began immediately at the outset of the Reagan Administration in 1981.

Unlike rewriting policy guidelines, changing the way that the Board of Governors implements policy takes time. Each of the seven governors is appointed to a nonrenewable term of 14 years, with a new governor being appointed every two years. Although governors sometimes leave the Board before completing their terms, a President cannot normally change the Board's ideological majority during his first term in office. Reagan did not appoint a governor until 1982, did not have a majority of appointees on the Board until 1986, and not until August of 1987 were all seven governors Reagan appointees. Once Reagan appointees held a majority on the Board, however, bank merger policy could have loosened even without changes in the academic literature; as it happened, the new learning and contestable markets theories may have provided intellectual "cover" for an ideologically driven policy change.

\section{Statistical Model and Data}

Let $Q$ be the dependent variable in a binomial probit model of the Board's merger policy, where $Q=1$ when an application for merger is denied by the Board. The probit model estimates the probability of application denial, both before and after deregulation, as a function of market concentration, the market share and operating scale of the merging banks, branching barriers to entry, the presence of thrift institutions in the relevant market, and the political composition of the Board at the time of the merger order.

A pre-deregulation list of 248 horizontal merger applications was generated from merger

7. More recently, economists have begun to study whether banks tend to operate close to the efficient production frontier. Evanoff [8] surveyed this literature and concluded that technical inefficiencies are typically 20 to 30 percent of banking costs, a potential source of savings larger than scale economies. Because these studies did not appear in the literature in large numbers until 1990, the Board could not have incorporated their results in its 1983-1990 merger policy. 
orders published in the Federal Reserve Bulletin between 1963 and 1980, and a post-deregulation list of 168 horizontal merger applications was generated from the same source between 1983 and $1990 .^{8}$ The end points of the sample periods correspond with changes in the economics literature, the antitrust environment, and banking legislation. The Justice Department's antitrust authority to challenge bank mergers, and a market definition that distinguished commercial banks from thrift institutions, were established in the 1963 Philadelphia National Bank decision. ${ }^{9}$ The first merger order in which the Board recognized thrifts to be competitors of commercial banks was published in $1980 . .^{10}$ The 1982 DOJ Merger Guidelines, the bank deregulatory acts, and the first of the pivotal empirical studies mentioned above all occurred slightly before or coincident with 1983 . The first Justice Department challenge of a Board-approved merger under the 1982-84 Merger Guidelines occurred in 1990."

Every application for merger or acquisition published in the Federal Reserve Bulletin during the sample periods that had horizontal content (i.e., a joint presence in a geographic market prior to the application) was considered for the sample. When the published merger order did not identify explicitly a "relevant" geographic market, the smallest geographic area discussed in the order (city, county, or SMSA) was selected. A bank was considered to be acquired only if the transaction resulted in at least 50\% ownership of the acquired bank's stock. Mergers involving foreign banks, de novo banks, banks in weak financial condition, banks where managerial succession was at issue, and banks that were commonly controlled prior to the merger, were excluded, as well as mergers for which all of the explanatory variables in the model could not be observed.

In recent years, very few orders denying a merger have been published. Only 4 of the 168 merger orders in the 1983-1990 sample were outright denials. Although the low frequency of denials appears to be prima facie evidence of a relaxed merger stance by the Board, it might also reflect improved communication between Board staff and merger applicants early in the application process. When Board staff feels that the merger as proposed has competitive problems, the applicants often include in the application a proposal to divest questionable branches rather than risk being denied, thus avoiding the lost time and expense of refiling. This practice of "fix it first" occurred more frequently during the $1980 \mathrm{~s} .{ }^{12}$ In order to control for this change, whenever the merger order indicated that the Board's approval rested on such divestitures, the merger was treated as a denied application $(Q=1)$ between the approved (merged) firm and the banks or branches divested in the relevant market. This adjustment increased the number of post-deregulation denials to 20 . Although treating approvals conditional on divestitures as outright denials presents a measurement problem, this adjustment should not result in any serious bias. Since in these cases approval was clearly conditional on divestiture, it is just as clear that an application that did not include these divestitures would have been denied.

Herfindahl indices $(H H)$ were available for the post-1983 observations, but none of the stan-

8. Prior to 1970, all merger applications for which the Fed was the principal regulator appeared in the Federal Reserve Bulletin [9]. Since then, most merger decisions have been delegated to the regional Federal Reserve Banks. Merger orders are now published in the $F R B$ only if the Board has significant concerns about the competitive impact of the merger, the financial or organizational stability of the acquiring bank, or community reinvestment record of the acquirer.

9. In PNB [24], the Court ruled that the term commercial banking denotes an unique cluster of products and services (e.g., checking, trust administration, various kinds of credit) that at the time effectively insulated banks from competition by thrifts and other financial intermediaries.

10. See Federal Reserve Bulletin [9, July 1980, pp. 576-577].

11. See U.S. v. First Hawaiian [23].

12. See Holder [12, note 9]. 
dard measures of market concentration was uniformly available for the pre-1980 sample period. ${ }^{13}$ The number of commercial banks $(N)$ in the relevant market was reported in all merger orders, however, and can be used to construct a consistent measure of concentration across samples. Gilbert [10] reports on ten concentration-profit studies that used $N$ to measure concentration. $N$ had a significant impact on profits in five of the studies, and in two of the others neither $N$ or more standard measures of concentration significantly impacted profits. This study uses the inverse of $N(N I N V)$ to measure concentration. NINV is theoretically superior to $N$ since it gives additional firms less weight as the number of market competitors increases, and NINV was more highly correlated with $H H(+.69)$ than was $N(-.48)$ for the post-1983 observations. Since NINV is a bank-only measure, a thrift dummy $(T H)$ was included in the post-1983 tests to control for competition from thrifts, where $T H=1$ when the merger order characterized thrift competition as "significant." 14

Market share was measured by the share of total commercial bank deposits in the relevant market held by the larger $(S 1)$ and the smaller $(S 2)$ of the merging organizations. The change in the Herfindahl index $(\Delta H H=2 \cdot S 1 \cdot S 2)$ measures the increase in market concentration due to the merger. Entry barriers were measured by a branching dummy $(B P)$, where $B P=1$ when the merger occurred in a unit banking or limited branch banking state. ${ }^{15}$ Scale was measured by the amount of deposits, in millions of 1980 dollars, held by the larger (Dl) and smaller (D2) banks in the relevant geographic market. The post-1983 political composition of the Board was measured by the percentage of governors on the date of the merger order that had been appointed by President Reagan (\%RR). Table I has summary statistics for all variables.

The probit model was specified as follows:

$$
\begin{aligned}
Q= & \Phi\left[\beta_{0}+\beta_{1} \cdot N I N V+\beta_{2} \cdot S 1+\beta_{3} \cdot S 2+\beta_{4} \cdot \Delta H H+\beta_{5} \cdot \Delta H H \cdot B P+\beta_{6} \cdot B P\right. \\
& \left.+\beta_{7} \cdot D 1+\beta_{8} D 2+\beta_{9} \cdot(D 2-X) \cdot D S+\beta_{10} \cdot T H+\beta_{11} \cdot \% R R+\varepsilon\right] .
\end{aligned}
$$

$\beta_{N I N V}$ and $\beta_{\Delta H H}$ are expected to be positive prior to 1980 , reflecting the antitrust policies of the time. $\beta_{N I N V}$ and $\beta_{\Delta H H}$ will be smaller or statistically insignificant in the later sample if the Board embraced the de-emphasis of concentration in the industrial organization literature. ( $H H$ will be used in place of NINV in alternate post- 1983 specifications, and is expected to behave similarly.) $\beta_{S I}$ and $\beta_{S 2}$ are both expected to be positive prior to 1980, but could become negative after 1983 if the Board identified large banks with efficient operations and hence desired that assets flow toward these firms.

$B P$ enters the model both linearly and interactively with $\Delta H H . \beta_{B P}$ is expected to be positive in both samples; a merger is more likely to increase market power in branching-restricted states because the competitor lost to merger must be replaced by a new entrant. De novo banks require fixed start-up costs (a charter, a board of directors, developing goodwill) that an already existing bank branching into the same market does not. $\beta_{B P}$ may be smaller after 1983 if the Board's policy anticipated the phase-out of state branching laws in the $1980 \mathrm{~s}$. $\beta_{\triangle H H \cdot B P}$ will be

13. Until 1987 the Board calculated a bank-only Herfindahl index, after which it used an adjusted Herfindahl index that gave market deposits in thrifts a 50\% weight. Herfindahl indices constructed from the Summary of Deposit data also are inadequate, since the geographic markets used in this source do not always match the relevant market in the merger orders.

14. For an example, see Federal Reserve Bulletin [9, August 1984, p. 652, note 7].

15. The $B P$ variable was constructed from Amel [1]. 
Table I. Summary Statistics, Dollars in Millions

\begin{tabular}{|c|c|c|c|c|}
\hline & \multicolumn{2}{|c|}{$1963-1980$} & \multicolumn{2}{|c|}{$1983-1990$} \\
\hline & mean & standard deviation & mean & standard deviation \\
\hline$N I N V$ & .0871 & .0809 & .0798 & .0645 \\
\hline$H H$ & - & - & 1831 & 739 \\
\hline$\Delta H H$ & 248 & 557 & 241 & 333 \\
\hline$S I$ & $17.79 \%$ & $14.71 \%$ & $19.59 \%$ & $12.68 \%$ \\
\hline$S 2$ & $4.45 \%$ & $5.87 \%$ & $5.23 \%$ & $5.63 \%$ \\
\hline$D I$ & $\$ 404.29$ & $\$ 777.97$ & $\$ 932.52$ & $\$ 2053.67$ \\
\hline D2 & $\$ 39.74$ & $\$ 64.78$ & $\$ 167.15$ & $\$ 454.66$ \\
\hline \multirow[t]{2}{*}{$\% R R$} & - & - & .6180 & .3284 \\
\hline & $=0$ & $=1$ & $=0$ & $=1$ \\
\hline$Q$ & 164 & 84 & 148 & 20 \\
\hline$B P$ & 124 & 124 & 136 & 32 \\
\hline$T H$ & - & - & 97 & 71 \\
\hline
\end{tabular}

positive if the Board was more sensitive to concentration in markets where entry barriers were high, particularly in the post-1983 model given the emphasis on entry barriers in the revised Merger Guidelines.

$T H$ and $\% R R$ appear only in the post- 1983 model. $\beta \% R R$ is expected to be negative if governors appointed by Reagan were less disposed to market intervention than governors appointed by Reagan's predecessors. $\beta_{T H}$ is expected to be negative, since the presence of additional nonbank competitors should reduce the likelihood of denial.

If the Board was at all sensitive to merger-induced efficiencies, the coefficients on the $D I$ and $D 2$ variables might capture the relationship between the banking cost literature and Board's merger policy. The probit specification shown above employs a spline function built around $D 2$, where $X$ is assumed to be the Board's perception of minimum efficient scale (MES), and DS is a dummy variable equal to one when $D 2>M E S$. Thus, $\beta_{D 2}$ measures the responsiveness of the Board to changes in scale below $M E S$, and $\beta_{D 2}+\beta_{D 2-X}$ measures the same thing for changes in scale above $M E S$. (The model will be estimated for various values of $X$.) If the Board considered the potential for scale economies, $\beta_{D 2}$ will be positive (i.e., as the target bank moves closer to $M E S$, the potential for scale economies from the merger decreases, so the probability of denial increases). $\beta_{D 2}+\beta_{D 2-X}$ is expected to be zero if scale had no effect on the probability of denial beyond MES. Of course, the Board's perception of MES before 1980 or after 1983 is not known. Furthermore, only one of the merger orders mentioned scale economies as a reason for approving a merger, so a statistically significant $\beta_{D 2}$ may capture some other, scale-related feature of Board policy. ${ }^{16} \mathrm{Dl}$ enters the model as a linear variable, because the average acquiring bank in the samples had probably exhausted opportunities for significant scale economies (see Table I). $\beta_{D 1}$ is expected to be positive.

16. See Federal Reserve Bulletin [9, December 1987, p. 923]. In discussions on this issue, long-time Board staff members indicated to the author that the Board has never practiced an efficiencies defense, either before or after deregulation. 
Table II. Goodness of Fit Measures from Probit Spline Regressions

\begin{tabular}{|c|c|c|c|c|c|c|}
\hline \multirow[b]{3}{*}{$D 2(\$ M)$} & \multirow{2}{*}{\multicolumn{2}{|c|}{$\begin{array}{c}1963-80 \\
\text { NINV }\end{array}$}} & \multicolumn{4}{|c|}{$1983-90$} \\
\hline & & & \multicolumn{2}{|c|}{ NINV } & \multicolumn{2}{|c|}{$H H$} \\
\hline & $R^{2}$ & $-\ln (£)$ & $R^{2}$ & $-\ln (£)$ & $R^{2}$ & $-\ln (\mathfrak{£})$ \\
\hline$\$ 10$ & .3962 & 101.7 & .5786 & 20.6 & .5853 & 20.3 \\
\hline 20 & .4356 & 96.7 & .5893 & 19.5 & .6011 & 19.1 \\
\hline 25 & .4320 & 97.4 & .5887 & 19.4 & .5996 & 19.1 \\
\hline 30 & .4371 & 96.9 & .5905 & 19.3 & .5991 & 19.0 \\
\hline 35 & .4441 & 96.0 & .5916 & 19.3 & .5998 & 19.0 \\
\hline 40 & .4458 & 95.8 & .5908 & 19.3 & .5988 & 19.0 \\
\hline 45 & .4497 & 95.1 & .5918 & 19.3 & .5998 & 18.9 \\
\hline 50 & .4512 & 95.0 & .5892 & 19.4 & .5972 & 19.0 \\
\hline 55 & .4493 & 95.1 & .5871 & 19.6 & .5940 & 19.2 \\
\hline 60 & .4466 & 95.3 & .5856 & 19.7 & .5919 & 19.3 \\
\hline 70 & .4461 & 95.4 & .5836 & 19.9 & .5887 & 19.5 \\
\hline 80 & .4450 & 95.5 & .5822 & 20.0 & .5865 & 19.6 \\
\hline 90 & .4403 & 95.7 & .5811 & 20.1 & .5849 & 19.7 \\
\hline 100 & .4380 & 95.7 & .5804 & 20.2 & .5838 & 19.8 \\
\hline 150 & .4380 & 95.4 & .5817 & 20.2 & .5834 & 19.9 \\
\hline 200 & .4301 & 95.8 & .5836 & 20.2 & .5845 & 19.9 \\
\hline 500 & \multicolumn{2}{|c|}{ did not converge } & .5808 & 20.4 & .5827 & 20.1 \\
\hline 1000 & \multicolumn{2}{|c|}{ did not converge } & .5802 & 20.4 & .5821 & 20.1 \\
\hline
\end{tabular}

\section{Results}

Goodness-of-fit statistics (adjusted $R^{2}$ and log-likelihood ratio) for the pre-1980 and post-1983 models, estimated using values of $X$ between $\$ 10$ million and $\$ 1,000$ million, are shown in Table II. Assuming that the value of $X$ that maximizes the model's fit is the Board's implicit definition of MES, the results in Table II offer at most only weak evidence that the Board revised its working definition of MES downward along with changes in the banking cost literature. Pre1980 fit clearly peaks at $X=\$ 50$ million, while post-1983 fit is maximized between $X=\$ 20$ and $X=\$ 45 .{ }^{17}$

The results of the best-fitting spline regressions (pre-1980 $X=\$ 50$ million, post- $1983 X=$ $\$ 45$ million) are shown in Tables III and IV along with alternate specifications. $S 1$ and $S 2$ are excluded from equations (1), (4), and (7), while $\Delta H H$ and $\Delta H H \cdot B P$ are excluded from equations (3), (6), and (9). $\triangle H H$ is related to the market share variables by construction, and although this relationship is not linear, these two sets of variables share the same information and as a result are not orthogonal. Thus, these six alternate specifications were estimated in order to (a) observe whether possible colinearity between these variables affects the estimated standard errors of the parameters, and (b) estimate separately the impacts of the $\Delta H H$ variables and the market share variables on the probability of Board denial.

17. The best pre-1980 fit $\left(X=\$ 50 \mathrm{M}, R^{2}=.4512\right)$ was statistically different from the worst pre-1980 fit $(X=$ $\left.\$ 10 \mathrm{M}, R^{2}=.3962\right)$ at the $15 \%$ level of significance. The best and worst post- 1983 fits were different at only the $29 \%$ level. To get these results, the sum of squared errors (ESS) from the poorer fitting model was divided by ESS from the better fitting model. The resulting ratio follows an $F$ distribution with identical degrees of freedom in the numerator and denominator $[17,149]$. This procedure is appropriate for comparing $R^{2}$ 's since $E S S$ is the only element in the $R^{2}$ 's that varies across models. 
Table III. Probit Estimations, 1963-1980

\begin{tabular}{|c|c|c|c|}
\hline & (1) & (2) & (3) \\
\hline$C$ & $\begin{array}{r}-3.1105^{\mathrm{a}} \\
(.4380)\end{array}$ & $\begin{array}{r}-4.0009^{\mathrm{a}} \\
(.5237)\end{array}$ & $\begin{array}{r}-3.5982^{\mathrm{a}} \\
(.4711)\end{array}$ \\
\hline NINV & $\begin{array}{l}10.2220^{\mathrm{a}} \\
(2.5069)\end{array}$ & $\begin{array}{r}6.2082^{b} \\
(2.7236)\end{array}$ & $\begin{array}{r}6.0946^{\mathrm{b}} \\
(2.8094)\end{array}$ \\
\hline$S 1$ & - & $\begin{array}{c}.0589^{a} \\
(.0121)\end{array}$ & $\begin{array}{c}.0514^{\mathrm{a}} \\
(.0105)\end{array}$ \\
\hline$S 2$ & - & $\begin{array}{c}.1199^{b} \\
(.0479)\end{array}$ & $\begin{array}{c}.0647 \mathrm{~b} \\
(.0305)\end{array}$ \\
\hline$\Delta H H$ & $\begin{array}{c}.0023^{\mathrm{a}} \\
(.0007)\end{array}$ & $\begin{array}{r}-.0004 \\
(.4321)\end{array}$ & - \\
\hline$\Delta H H \cdot B P$ & $\begin{array}{r}-.0014^{c} \\
(.0008)\end{array}$ & $\begin{array}{r}-.0011^{\mathrm{c}} \\
(.0007)\end{array}$ & - \\
\hline$B P$ & $\begin{array}{c}.7833^{\mathrm{a}} \\
(.2715)\end{array}$ & $\begin{array}{c}.8069^{\mathrm{a}} \\
(.2808)\end{array}$ & $\begin{array}{c}.5238^{b} \\
(.2275)\end{array}$ \\
\hline$D I$ & $\begin{array}{c}.0003^{b} \\
(.0001)\end{array}$ & $\begin{array}{c}.0001 \\
(.0002)\end{array}$ & $\begin{array}{c}.0001 \\
(.0002)\end{array}$ \\
\hline D2 & $\begin{array}{c}.0328^{\mathrm{a}} \\
(.0072)\end{array}$ & $\begin{array}{c}.0401^{\mathrm{a}} \\
(.0081)\end{array}$ & $\begin{array}{c}.0396^{\mathrm{a}} \\
(.0080)\end{array}$ \\
\hline$(D 2-X) \cdot D S$ & $\begin{array}{r}-.0349^{\mathrm{a}} \\
(.0077)\end{array}$ & $\begin{array}{r}-.0383^{\mathrm{a}} \\
(.0085)\end{array}$ & $\begin{array}{r}-.0382^{\mathrm{a}} \\
(.0084)\end{array}$ \\
\hline adjusted $R^{2}$ & .3785 & .4512 & .4406 \\
\hline$\Phi$ & $33.85 \%$ & $26.93 \%$ & $29.13 \%$ \\
\hline
\end{tabular}

Notes: Dependent variable is $Q . N=248 . X=\$ 50$ million. Standard errors are in parentheses. Superscripts a, b, and $\mathrm{c}$ indicate significance at the 1,5 , and 10 percent levels, respectively.

The results in Table IV suggest that some of the standard errors were exaggerated by colinearity in the post-1983 data. When $S 1$ and $S 2$ are included in the post-1983 model, $\beta_{\triangle H H \cdot B P}$, $\beta_{N I N V}$, and $\beta_{H H}$ all lose their statistical significance even though their magnitudes remained relatively unchanged.$^{18}$ Removing $S 1$ and $S 2$ apparently results in a specification error. In the post1983 model, $R^{2}$ falls significantly and the absolute sizes of estimated $\beta_{D 1}, \beta_{D 2}$, and $\beta_{(D 2-X) \cdot D S}$ are sharply lower. $R^{2}$ also falls in the pre- 1980 model, but the estimated parameters and standard errors for these three variables are relatively unaffected..$^{19}$

Comparing the results across equations (1), (4), and (7) may reveal a change in the Board's policy with respect to entry barriers after 1983. Prior to $1980, \beta_{B P}$ and $\beta_{\triangle H H}$ were both positive and highly significant and $\beta_{\Delta H H \cdot B P}$ was negative and significant. While these results indicate that the Board was less likely to approve mergers in markets where entry was difficult, or mergers that increased concentration by large amounts, the results also suggest that the Board did not become more sensitive to increases in concentration when entry was unlikely. In contrast, after

18. This diagnosis is supported by relatively high pair-wise correlations between these variables and the market share variables. In the post-1983 data, $\rho(S 1, N I N V)=.504, \rho(S 1, H H)=.598, \rho(S 2, N I N V)=.516$, and $\rho(S 2, \Delta H H)=.907$.

19. Using the test described in note 17, the adjusted $R^{2}$ values in equation pair (1), (2); equation pair (4), (5); and equation pair (7), (8) were significantly different from each other at the 10 percent, 1 percent, and 1 percent levels, respectively. Although pre-1980 correlations involving $S 1$ and $S 2$ were similar to the high post- 1983 correlations, the effects of colinearity were likely less serious due to the larger number of pre-1980 observations. 
Table IV. Probit Estimations, 1983-1990

\begin{tabular}{|c|c|c|c|c|c|c|}
\hline & (4) & (5) & (6) & (7) & (8) & (9) \\
\hline$C$ & $\begin{array}{r}-.9113 \\
(.6752)\end{array}$ & $\begin{array}{r}-4.6504^{b} \\
(2.3772)\end{array}$ & $\begin{array}{r}-4.2972^{\mathrm{a}} \\
(1.4337)\end{array}$ & $\begin{array}{r}-1.8814^{b} \\
(.8033)\end{array}$ & $\begin{array}{r}-5.0307^{b} \\
(2.4088)\end{array}$ & $\begin{array}{r}-4.7312^{\mathrm{a}} \\
(1.5942)\end{array}$ \\
\hline NINV & $\begin{array}{r}9.5493^{b} \\
(4.3572)\end{array}$ & $\begin{array}{c}9.0086 \\
(7.5770)\end{array}$ & $\begin{array}{c}9.0063 \\
(7.5089)\end{array}$ & - & - & - \\
\hline$H H$ & - & - & - & $\begin{array}{c}.0010^{\mathrm{a}} \\
(.0003)\end{array}$ & $\begin{array}{c}.0008 \\
(.0006)\end{array}$ & $\begin{array}{c}.0008 \\
(.0006)\end{array}$ \\
\hline$S 1$ & 一 & $\begin{array}{c}.1694^{\mathrm{a}} \\
(.0590)\end{array}$ & $\begin{array}{c}.1569^{\mathrm{a}} \\
(.0434)\end{array}$ & - & $\begin{array}{c}.1588^{a} \\
(.0551)\end{array}$ & $\begin{array}{c}.1519^{a} \\
(.0429)\end{array}$ \\
\hline$S 2$ & - & $\begin{array}{c}.0539 \\
(.1967)\end{array}$ & $\begin{array}{r}-.0664 \\
(.0649)\end{array}$ & - & $\begin{array}{c}.0664 \\
(.1947)\end{array}$ & $\begin{array}{r}-.0314 \\
(.0526)\end{array}$ \\
\hline$\Delta H H$ & $\begin{array}{c}.0005 \\
(.0006)\end{array}$ & $\begin{array}{r}-.0019 \\
(.0030)\end{array}$ & - & $\begin{array}{c}.0008 \\
(.0005)\end{array}$ & $\begin{array}{r}-.0016 \\
(.0029)\end{array}$ & - \\
\hline$\Delta H H \cdot B P$ & $\begin{array}{c}.0026^{b} \\
(.0013)\end{array}$ & $\begin{array}{c}.0022 \\
(.0020)\end{array}$ & - & $\begin{array}{r}.0026^{b} \\
(.0013)\end{array}$ & $\begin{array}{c}.0024 \\
(.0019)\end{array}$ & 一 \\
\hline$B P$ & $\begin{array}{r}-.5386 \\
(.6449)\end{array}$ & $\begin{array}{c}.2219 \\
(1.0130)\end{array}$ & $\begin{array}{c}.8986 \\
(.6093)\end{array}$ & $\begin{array}{r}-.3123 \\
(.6402)\end{array}$ & $\begin{array}{c}.4035 \\
(.9985)\end{array}$ & $\begin{array}{l}1.1442^{c} \\
(.6149)\end{array}$ \\
\hline$D I$ & $\begin{array}{r}-.0003 \\
(.0005)\end{array}$ & $\begin{array}{r}-.0020 \\
(.0013)\end{array}$ & $\begin{array}{r}-.0024^{b} \\
(.0012)\end{array}$ & $\begin{array}{r}-.0006 \\
(.0005)\end{array}$ & $\begin{array}{r}-.0024^{c} \\
(.0014)\end{array}$ & $\begin{array}{r}-.0028^{b} \\
(.0013)\end{array}$ \\
\hline$D 2$ & $\begin{array}{c}.0052 \\
(.0145)\end{array}$ & $\begin{array}{r}.0465^{b} \\
(.0273)\end{array}$ & $\begin{array}{r}.0529^{b} \\
(.0251)\end{array}$ & $\begin{array}{c}.0065 \\
(.0136)\end{array}$ & $\begin{array}{c}.0453^{c} \\
(.0268)\end{array}$ & $\begin{array}{c}.0525^{b} \\
(.0249)\end{array}$ \\
\hline$(D 2-X) \cdot D S$ & $\begin{array}{r}-.0045 \\
(.0145)\end{array}$ & $\begin{array}{r}-.0425 \\
(.0275)\end{array}$ & $\begin{array}{r}-.0481^{b} \\
(.0247)\end{array}$ & $\begin{array}{r}-.0055 \\
(.0136)\end{array}$ & $\begin{array}{r}-.0409 \\
(.0268)\end{array}$ & $\begin{array}{r}-.0475^{b} \\
(.0243)\end{array}$ \\
\hline$T H$ & $\begin{array}{r}-1.2707^{\mathrm{a}} \\
(.4586)\end{array}$ & $\begin{array}{r}-2.7269^{a} \\
(1.0076)\end{array}$ & $\begin{array}{r}-2.5558^{\mathrm{a}} \\
(.9225)\end{array}$ & $\begin{array}{r}-1.3342^{\mathrm{a}} \\
(.4748)\end{array}$ & $\begin{array}{r}-2.8906^{\mathrm{a}} \\
(1.0852)\end{array}$ & $\begin{array}{r}-2.6612^{\mathrm{a}} \\
(.9631)\end{array}$ \\
\hline$\% R R$ & $\begin{array}{r}-2.1806^{\mathrm{a}} \\
(.6561)\end{array}$ & $\begin{array}{r}-3.5583^{\mathrm{a}} \\
(1.2582)\end{array}$ & $\begin{array}{r}-3.6684^{\mathrm{a}} \\
(1.2666)\end{array}$ & $\begin{array}{r}-2.5890^{\mathrm{a}} \\
(.7613)\end{array}$ & $\begin{array}{r}-4.1223^{\mathrm{a}} \\
(1.4873)\end{array}$ & $\begin{array}{r}-4.1885^{\mathrm{a}} \\
(1.4848)\end{array}$ \\
\hline adjusted $R^{2}$ & .3893 & .5918 & .5742 & .4121 & .5988 & .5775 \\
\hline$\Phi$ & $2.70 \%$ & $0.01 \%$ & $0.01 \%$ & $1.36 \%$ & $0.01 \%$ & $0.01 \%$ \\
\hline
\end{tabular}

Notes: Dependent variable is $Q . N=168 . X=\$ 45$ million. Standard errors are in parentheses. Superscripts a, b, and $c$ indicate significance at the 1,5 , and 10 percent levels, respectively.

1983 neither $B P$ or $\triangle H H$ by themselves had a significant impact on the probability of denial, but $\beta_{\triangle H H \cdot B P}$ was positive and significant. These results suggest that the Board reacted strongly to large increases in concentration only when it was unlikely that entry would mitigate the reduction in competition. The significance of $\beta_{\triangle H H \cdot B P}$ (coupled with the insignificance of $\beta_{B P}$ and $\beta_{\triangle H H}$ ) after 1983 is consistent with the more sophisticated joint treatment of concentration and entry barriers in the 1982-84 Merger Guidelines. The insignificance of $\beta_{B P}$ after 1983 may also indicate that the Board was anticipating the eventual phase-out of intra-state branching restrictions.

Prior to $1980, \beta_{N I N V}, \beta_{S 1}$, and $\beta_{S 2}$ had the expected signs and were statistically significant, evidence that the Board was more likely to deny mergers between firms with high market shares and/or mergers in highly concentrated markets. After 1983, $\beta_{\text {NINV }}$ was approximately the same size, and remained statistically significant (albeit at a slightly lower level) in equation (4). $\beta_{H H}$ followed the same pattern as $\beta_{N I N V}$. Although interpretation of these results requires some judgement given the probable presence of colinearity in the post-1983 data, they suggest that 
the Board's treatment of market concentration remained roughly constant across time, despite the attention given to efficient-structure theories in the theoretical and empirical literature. Moreover, the significant negative coefficients that would indicate a conversion to a Chicago school ideology were not present on either market share variable. $\beta_{S I}$ remained significant and nearly tripled in size, but $\beta_{S 2}$ lost its statistical significance. This combination of changes in the market share coefficients may indicate an increased concern about markets with dominant firms. ${ }^{20}$

After 1983, the Board appears to have integrated its analysis of concentration and market share with other market conditions. As discussed above, the Board's concern about increases in concentration appeared to be limited to markets where entry was difficult. The loss of significance of both $\beta_{S 2}$ and $\beta_{B P}$ after 1983, together with the significant and negative $\beta_{T H}$, may indicate that, in the Board's view, the larger number of potential competitors in the post-deregulation environment made the loss of an existing competitor less serious.

In February 1985, the Justice Department announced that it would not ordinarily challenge a bank merger unless the Herfindahl index exceeded 1800 in the relevant market and increased by more than 200 points as a result of the merger. ${ }^{21}$ Alternate versions of equations (4), (5), (7), and (8) were estimated (not shown) to test whether the "1800/200" rule had an impact on denial above and beyond the other variables in the model. In these equations, $\triangle H H \cdot B P$ was replaced by two other variables: $D 1800$, a dummy equal to one when $H H>1800$, and the interactive variable $D 1800 \cdot \Delta H H . \beta_{D 1800}$ was positive throughout but was significant in only one of the four equations, and $\beta_{D 1800} \cdot \Delta H H$ was negative and nonsignificant throughout. These results are consistent with those found by Holder [13], who, in an extensive analysis of the mitigating factors cited by the Board in approved merger applications, found that the $1800 / 200$ rule was seldom binding.

Before $1980, \beta_{D 2}$ was positive and significant, $\beta_{D 2-X}$ was negative and significant, and their sum was not significantly different from zero. ${ }^{22}$ Hence, the Board was less likely to deny a merger the more sub-optimal the smaller bank, but was indifferent to increases in scale when the smaller bank was above $\$ 50$ million in assets. $\beta_{D I}$ was positive and small, and was significantly different from zero only in equation (1) - since the average acquiring bank had well over $\$ 50$ million in assets, the results for $D 1$ and $D 2$ are consistent with each other. Overall, the scale coefficients were relatively unchanged after $1983 .{ }^{23} \beta_{D 2}$ and $\beta_{D 2-X}$ maintained nearly the same size and significance in equations (5), (6), (8), and (9) as in the pre-1980 equations. $\beta_{D I}$ turned negative but remained small, and was insignificant in half of the post-1983 equations. Although both the pre-1980 and post-1983 results are consistent with a policy encouraging mergers that removed sub-optimal banks from the market, there is little corroborating evidence that the Board

20. Citing three post-1983 merger applications as examples, Holder [13, 39-40] reports that when market concentration was driven by the shares of one or two dominant firms, this fact "worked in favor of mergers that involved other institutions in the market and against approval of transactions involving the dominant firm(s)."

21. See Holder [12, 31]. Of the 168 merger orders in the post-1983 sample, 120 came after 1985 . Of these 120 , 35 exceeded the $1800 / 200$ threshold. Of these 35 , the Board denied (or would have denied had the application not been restructured) only 7.

22. The following procedure was used to test the hypothesis that $\beta_{D 2}+\beta_{D 2-X}=0$. A linear (non-spline) specification model was estimated for a subsample that included only applications having $D 2>X$. In these tests, $\beta_{D 2}$ was not significantly different from zero in the pre-1980 or post-1983 versions of this model.

23. Alternate specifications (not shown) were estimated using the natural $\log$ of $D 2$ in place of the spline variables $(D 2$ and $(D 2-X) \cdot D S)$. The natural $\log$ shape $(\ln D 2)$ mimics the pre-1980 Cobb-Douglas estimates of continuous, though diminishing, scale economies for all sizes of banks. $\beta_{\ln D 2}$ was positive and highly significant (1 percent level) in pre-1980 regressions, but was positive and statistically insignificant in post-1983 regressions. Compared to the spline model, the natural log model provided a worse fit for the post-1983 data $\left(R^{2}\right.$ of .5591 vs. .5998 for the spline $)$ and about the same fit for the pre-1980 data $\left(R^{2}\right.$ of .4621 vs. .4512 for the spline). 
was practicing an efficiencies defense, and these results may be capturing some other scale-related phenomenon. Regardless, there is no evidence here that the Board changed its treatment of scale in response to changes in the banking cost literature.

To the extent that the above results represent actual changes in the Board's merger policy, they occurred simultaneous with an across-the-board easing of merger policy. As expected, as more of the governors became Reagan appointees, the probability of denial grew smaller $-\beta \% R R$ was negative and statistically significant. The estimated probability $\Phi$ that the average merger application (i.e., an application having sample means for each variable) would have been denied was between 26 and 34 percent between 1963 and 1980. After 1983, average $\Phi$ fell below 3 percent, a change that is consistent with a series of non-mutually exclusive explanations: (1) earlier contact with Board staff resulted in divestitures of questionable branches prior to filing the application, (2) the 1980s Justice Department Merger Guidelines-as implemented by the Board-presented clearer standards for banks than did the 1968 Guidelines, (3) bank merger policy relaxed in recognition of the increase in actual and potential competition after deregulation, and (4) bank merger policy became more lax due to a change in ideology at the Board.

Simulations that evaluate equations (2) and (5) for 36 hypothetical merger scenarios are shown in Table V. The scenarios are organized into three groups that bracket the concentration thresholds in the 1982-84 Merger Guidelines as amended for bank mergers. ${ }^{24}$ Under these Guidelines, mergers in group A were unlikely to be challenged; mergers in group $\mathrm{C}$ were likely to be challenged; and mergers in group B were less likely to be challenged if they caused efficiency gains but more likely to be challenged if entry barriers were high. The superscript $A$ denotes "predicts approval" ( $D$ denotes "predicts denial"), and appears whenever the probability 0.500 fell above (below) a $90 \%$ confidence interval around estimated $\Phi$.

Under the pre-1980 regime, there was a high degree of statistical certainty that 12 mergers would have been denied, and 12 mergers would have been approved. After 1983, the ratio of approvals to denials remained reasonably unchanged prior to the Reagan appointments (i.e., in simulations with \%RR set equal to zero), with a high degree of certainty that 14 mergers would have been denied, and 9 mergers would have been approved. This contrasts dramatically with the results of the simulation after the Reagan appointments (i.e., \%RR set equal to 1) in which 33 mergers would have been approved and none denied. While this exercise demonstrates forcefully the extent to which merger policy relaxed as additional Reagan appointees joined the Board, the results to not allow us to differentiate between explanations (3) and (4) above-the results may reflect the change in the Board's ideological composition, or they may reflect a recognition of increased competition that occurred coincidentally with the Reagan appointments. Moreover, any conclusion that ideology completely dominated economic analysis in the Board's post-1983 merger policy would have to ignore the statistically significant coefficients on concentration, acquiring bank market share, and the presence of thrift competitors in the post-1983 model.

24. See the 1982 and 1984 U.S. Department of Justice Merger Guidelines [25] and Federal Reserve Bulletin [9, October 1985, p. 796, note 10]. $T H$ was set to zero in equation (5) for all 36 scenarios. Since $H H$ was not available for both samples, post-deregulation data was used to estimate (OLS) the following model:

$$
\begin{aligned}
\text { NINV }= & -.031916+.000060 \cdot H H+.011742 \cdot B P \\
& (.009813) \quad(.000005)
\end{aligned}
$$

the results of which were used to produce values for NINV that correspond to the $H H$ scenario values of 1400,1800 , and 2500 in Table V. 
Table V. Probability of Denial for Hypothetical Merger Scenarios
(2) $(5, \% R R=0)(5, \% R R=1)$

$\Phi \quad \Phi$

A. $H H=1400, \Delta H H=50$

\begin{tabular}{|c|c|c|c|c|c|c|c|}
\hline $.036^{\mathrm{A}}$ & $.020^{\mathrm{A}}$ & $.000^{\mathrm{A}}$ & $5.0 \%$ & $5.0 \%$ & 0 & $\$ 25 \mathrm{M}$ & $\$ 25 \mathrm{M}$ \\
\hline $.036^{\mathrm{A}}$ & $.068^{\mathrm{A}}$ & $.000^{\mathrm{A}}$ & 10.0 & 2.5 & 0 & 25 & 100 \\
\hline $.089^{A}$ & .316 & $.000^{\mathrm{A}}$ & 20.0 & 1.25 & 0 & 25 & 400 \\
\hline $.168^{A}$ & $.053^{\mathrm{A}}$ & $.000^{\mathrm{A}}$ & 5.0 & 5.0 & 1 & 25 & 25 \\
\hline $.163^{\mathrm{A}}$ & $.146^{\mathrm{A}}$ & $.000^{\mathrm{A}}$ & 10.0 & 2.5 & 1 & 25 & 100 \\
\hline $.299^{\mathrm{A}}$ & .484 & $.000^{\mathrm{A}}$ & 20.0 & 1.25 & 1 & 25 & 400 \\
\hline $.306^{\mathrm{A}}$ & $.146^{\mathrm{A}}$ & $.000^{\mathrm{A}}$ & 5.0 & 5.0 & 0 & 100 & 100 \\
\hline $.241^{\mathrm{A}}$ & $.170^{\mathrm{A}}$ & $.000^{\mathrm{A}}$ & 10.0 & 2.5 & 0 & 100 & 400 \\
\hline .418 & $.037^{\mathrm{A}}$ & $.000^{\mathrm{A}}$ & 20.0 & 1.25 & 0 & 100 & 1600 \\
\hline .545 & .270 & $.000^{\mathrm{A}}$ & 5.0 & 5.0 & 1 & 100 & 100 \\
\hline .548 & .303 & $.000^{\mathrm{A}}$ & 10.0 & 2.5 & 1 & 100 & 400 \\
\hline $.732^{\mathrm{D}}$ & $.090^{\mathrm{A}}$ & $.000^{\mathrm{A}}$ & 20.0 & 1.25 & 1 & 100 & 1600 \\
\hline
\end{tabular}

B. $H H=1800, \Delta H H=200$

$\begin{array}{lllllllr}.206^{\mathrm{A}} & .157^{\mathrm{A}} & .000^{\mathrm{A}} & 10.0 \% & 10.0 \% & 0 & \$ 25 \mathrm{M} & \$ 25 \mathrm{M} \\ .204^{\mathrm{A}} & .604 & .000^{\mathrm{A}} & 20.0 & 5.0 & 0 & 25 & 100 \\ .332^{\mathrm{A}} & .946^{\mathrm{D}} & .026^{\mathrm{A}} & 30.0 & 3.33 & 0 & 25 & 225 \\ .433 & .408 & .000^{\mathrm{A}} & 10.0 & 10.0 & 1 & 25 & 25 \\ .431 & .851^{\mathrm{D}} & .006^{\mathrm{A}} & 20.0 & 5.0 & 1 & 25 & 100 \\ .587 & .992^{\mathrm{D}} & .121^{\mathrm{A}} & 30.0 & 3.33 & 1 & 25 & 225 \\ .606 & .496 & .000^{\mathrm{A}} & 10.0 & 10.0 & 0 & 100 & 100 \\ .607 & .788 & .003^{\mathrm{A}} & 20.0 & 5.0 & 0 & 100 & 400 \\ .753^{\mathrm{D}} & .916^{\mathrm{D}} & .015^{\mathrm{A}} & 30.0 & 3.33 & 0 & 100 & 900 \\ .822^{\mathrm{D}} & .778 & .003^{\mathrm{A}} & 10.0 & 10.0 & 1 & 100 & 100 \\ .823^{\mathrm{D}} & .943^{\mathrm{D}} & .024^{\mathrm{A}} & 20.0 & 5.0 & 1 & 100 & 400 \\ .910^{\mathrm{D}} & .984^{\mathrm{D}} & .081^{\mathrm{A}} & 30.0 & 3.33 & 1 & 100 & 900\end{array}$

C. $H H=2500, \Delta H H=300$

\begin{tabular}{|c|c|c|c|c|c|c|c|}
\hline .438 & .396 & $.000^{\mathrm{A}}$ & $12.5 \%$ & $12.5 \%$ & 0 & $\$ 25 \mathrm{M}$ & $\$ 25 \mathrm{M}$ \\
\hline $.378^{\mathrm{A}}$ & .742 & $.002^{\mathrm{A}}$ & 20.0 & 7.5 & 0 & 25 & 67 \\
\hline .493 & $.979 \mathrm{D}$ & $.065^{\mathrm{A}}$ & 30.0 & 5.0 & 0 & 25 & 150 \\
\hline .649 & .770 & $.002^{\mathrm{A}}$ & 12.5 & 12.5 & 1 & 25 & 25 \\
\hline .591 & $.951^{D}$ & $.028^{A}$ & 20.0 & 7.5 & 1 & 25 & 67 \\
\hline $.699^{D}$ & $.998^{\mathrm{D}}$ & .252 & 30.0 & 5.0 & 1 & 25 & 150 \\
\hline $.825^{\mathrm{D}}$ & .768 & $.002^{\mathrm{A}}$ & 12.5 & 12.5 & 0 & 100 & 100 \\
\hline $.784^{\mathrm{D}}$ & $.918^{\mathrm{D}}$ & $.015^{A}$ & 20.0 & 7.5 & 0 & 100 & 267 \\
\hline $.862^{\mathrm{D}}$ & $.986^{\mathrm{D}}$ & $.099^{A}$ & 0.0 & 5.0 & 0 & 100 & 600 \\
\hline $.848^{\mathrm{D}}$ & $.880^{\mathrm{D}}$ & $.008^{A}$ & 12.5 & 12.5 & 1 & 100 & 100 \\
\hline $.908^{\mathrm{D}}$ & $.992^{\mathrm{D}}$ & .122 & 20.0 & 7.5 & 1 & 100 & 267 \\
\hline $.949^{D}$ & 999D & .387 & 30.0 & 5.0 & 1 & 100 & 600 \\
\hline
\end{tabular}

Note: Superscripts A and D indicate projected approval and denial at 90 percent confidence level. 
The post-1983/pre-Reagan simulation results (second column in Table V) suggest that the Board's merger policy conformed to the revised Merger Guidelines. None of the "unlikely to be challenged" group A scenarios were denied, and none of the "likely to be challenged" group C scenarios were approved. Consistent with the attention paid to entry barriers in the revised Guidelines, four of the six denials in the "likely to be challenged if" group B scenarios occurred where $B P=1$. Note that the majority of the pre-1980 approvals (10 of 12) occurred in scenarios with potential for scale economies (i.e., $D 2=\$ 25$ million), but no similar pattern shows up in the post-1983 results.

\section{Conclusions}

During the early 1980s a confluence of events changed the economic, political, and regulatory underpinnings of bank merger policy. Decades old regulations of financial institutions were phased out, the Justice Department relaxed its overall merger antitrust policy, and appointments by President Reagan changed the ideological composition of the Federal Reserve Board of Governors. In addition, the scholarly literature in economics challenged the conventional wisdom regarding the impact of market concentration and bank scale on bank performance. This study finds evidence that the Board of Governor's bank merger policy responded to some, but not all, of these changes.

There is strong evidence that the Board's merger policy became progressively more lax throughout the 1980s. Merger simulations based on a model estimated from the Board's actual merger decisions suggest that the percentage of governors appointed by President Reagan was a strong determinant of bank merger policy. A simulated Board comprised entirely of Reagan appointees approved 33 of 36 hypothetical mergers, including a majority of scenarios characterized as "likely to be challenged" under the 1982-84 Merger Guidelines. Although it is tempting to attribute this relaxation to the laissez faire ideology of the Reagan appointees, it is equally possible that the Board adjusted its policies as the post-deregulation environment facing banks became increasingly competitive. Indeed, the results found here show that the Board relaxed its policy more in markets where thrift competition was significant.

While it appears that the Board did alter its treatment of market structure after 1983, the changes fell far short of abandoning the structure-performance paradigm in favor of an efficientstructure approach. For example, the Board remained more likely to deny mergers in highly concentrated markets, and its sensitivity to the market share of the acquiring bank increased. Furthermore, the post-1983 results suggest that (in contrast to the pre-1980 results) the Board became more sensitive to merger-induced increases in concentration when entry barriers were present, a more sophisticated policy consistent with revisions in the Justice Department's 1982 and 1984 Merger Guidelines.

The Board was less likely to deny acquisitions of sub-optimal size banks both before and after 1980. Although these results suggest a merger policy that encouraged removing sub-optimal banks from the market, there is little corroborating evidence that the Board practiced an efficiencies defense in either time period. Moreover, there was only marginal evidence that the Board changed its treatment of scale in response to changes in the banking cost literature. 


\section{References}

1. Amel, Dean F. "State Laws Affecting Commercial Bank Branching, Multibank Holding Company Expansion, and Interstate Banking." Unpublished manuscript, Board of Governors of the Federal Reserve System, 1991.

2. Bank Merger Act, Public Law 89-356, February 21, 1966.

3. Baumol, William J., John C. Panzar, and Robert D. Willig. Contestable Markets and the Theory of Industrial Structure. New York: Harcourt Brace Jovanovich, 1982.

4. Benston, George J., Gerald A. Hanweck, and David B. Humphrey, "Scale Economies in Banking: A Restructuring and Reassessment." Journal of Money, Credit, and Banking, November 1982, 435-56.

5. Berger, Allen N. and Timothy H. Hannan, "The Price-Concentration Relationship in Banking." The Review of Economics and Statistics, May 1989, 291-99.

6. Clark, Jeffrey A., "Economies of Scale and Scope At Depository Institutions: A Review of the Literature." Federal Reserve Bank of Kansas City, Economic Review, September 1988, 16-33.

7. Demsetz, Harold, "Industry Structure, Market Rivalry, and Public Policy." Journal of Law and Economics, April 1973, 1-9.

8. Evanoff, Douglas D. and Philip R. Israilevich, "Productive Efficiency in Banking." Federal Reserve Bank of Chicago, Economic Perspectives, July 1991, 11-32.

9. Federal Reserve Bulletin, United States G.P.O., 1963-1990.

10. Gilbert, R. Alton, "Bank Market Structure and Competition." Journal of Money, Credit, and Banking, November $1984,617-45$.

11. Hannan, Timothy H., "Bank Commercial Loan Markets and the Role of Market Structure: Evidence from Surveys of Commercial Lending." Journal of Banking and Finance, February 1991, 133-49.

12. Holder, Christopher L., "Competitive Considerations in Bank Mergers and Acquisitions: Economic Theory, Legal Foundations, and the Fed." Federal Reserve Bank of Atlanta, Economic Review, January 1993, 23-36.

13. - "The Use of Mitigating Factors in Bank Mergers: A Decade of Antitrust at the Fed." Federal Reserve Bank of Atlanta, Economic Review, March 1993, 32-44.

14. Humphrey, David B. "Why Do Estimates of Bank Scale Economies Differ?" Federal Reserve Bank of Richmond, Economic Review, September 1990, 38-50.

15. - "Cost and Scale Economies in Bank Intermediaries," in Handbook for Banking Strategies, edited by Richard C. Aspinwall, and Robert A. Eisenbeis. New York: Wiley, 1985, pp. 745-83.

16. Mester, Loretta J., "Efficient Production of Financial Services: Scale and Scope Economies." Federal Reserve Bank of Philadelphia, Business Review, January 1987, 15-25.

17. Pindyck, Robert S. and Daniel L. Rubinfeld. Econometric Models and Economic Forecasts, 2nd edition. New York: McGraw-Hill, 1981.

18. Ravenscraft, David J. "Structure-Profit Relationships at the Line of Business and Industry Level." Review of Economics and Statistics, February 1983, 22-31.

19. Rhoades, Stephen, "Market Share as a Source of Power: Implications and Some Evidence," Journal of Economics and Business, 1985, 343-63.

20. Rhoades, Stephen A. and Jim Burke, "Economic and Political Foundations of Section 7 Enforcement in the 1980s." The Antitrust Bulletin, Summer 1990, 373-446.

21. Scherer, F. M. and David Ross. Industrial Market Structure and Economic Performance. Boston: Houghton Mifflin, 1990.

22. Smirlock, Michael, "Evidence on the (Non) Relationship between Concentration and Profitability in Banking." Journal of Money, Credit, and Banking, February 1985, 69-83.

23. U.S. v. First Hawaiian, CCH Trade Cases, P 69, 457 (1991).

24. U.S. v. Philadelphia National Bank, 374 U.S. 321 (1963).

25. U.S. Department of Justice, Merger Guidelines (1968, 1982, 1984).

26. Waldman, Don E. The Economics of Antitrust: Cases and Analysis. Boston: Little, Brown and Company, 1985.

27. Weiss, Leonard W. "The Concentration-Profits Relationship and Antitrust," in Industrial Concentration: The New Learning, edited by Harvey J. Goldschmid, H. Michael Mann, and J. Fred Weston. Boston: Little Brown, 1974, pp. 184-233.

28. Williamson, Oliver, "Economies as an Antitrust Defense: The Welfare Tradeoffs." American Economic Review, March 1968, 18-36. 